Disparitas Regional Antar Provinsi Di Indonesia 2011 - 2015 (Model Regresi Spasial)

Debby Marantika ${ }^{1^{*}}$, Teguh Hadi $\mathbf{P}^{2}$, Sebastiana Viphindrartin ${ }^{3}$

1,2,3 Jurusan Ilmu Ekonomi Pembangunan, Fakultas Ekonomi dan Bisnis, Universitas Jember (UNEJ)

\section{Informasi Artikel}

Sejarah artikel:

Diterima September 2017

Disetujui Februari 2018

Dipublikasikan Maret

2018

\section{Keywords:}

Disparity,

Gini Index

Spatial,

Spatial Lag.

\begin{abstract}
A BS TRACT
The purpose of this study is to analyze the impact of regional disparity by including spatial elements, and the variables that influence the level of disparity among provinces such as Gini Index as the dependent variable, PAD, GRDP per Capita, DAU, PMDN and PMA as independent variables. The data used in this research is panel data which then averaged by using spatial analysis method, where the selected model is spatial lag model by using Geoda software aid. The results of the analysis indicate that in each study area indicated spatial aspect, that the spatial aspect influences the level of regional disparity in Indonesia with negative direction. That is, if there is an increase of gini index value in the study area, then spatially, it will decrease the value of gini index in neighboring region. The independent variable in Region I PDRB Per Capita, DAU has significant influence, while other variables have no significant effect, Region II shows that all the variables significantly influence, while Region III PAD and PMDN have significant effect, other variables have no significant effect.
\end{abstract}




\section{Pendahuluan}

Pembangunan ekonomi merupakan suatu proses yang dilaksanakan dalam rangka menuju perekonomian negara menjadi lebih baik yang sifatnya jangka pendek, jangka menengah, dan jangka panjang berdasarkan kebijakan-kebijakan yang nantinya dapat mempengaruhi kondisi perekonomian. Pertumbuhan ekonomi disuatu wilayah merupakan suatu proses yang berkelanjutan untuk menuju pembangunan yang lebih baik. (Boediono, 1981:1) menjelaskan bahwa pertumbuhan ekonomi adalah proses kenaikan output per kapita dalam jangka panjang. Pertumbuhan ekonomi suatu wilayah biasanya juga dipengaruhi oleh mobilitas daerah-daerah tetangga yang ada. Profesor Bert Hoselitz, "pertumbuhan ekonomi merupakan suatu proses yang tidak hanya mempengaruhi hubungan ekonomi tetapi keseluruhan tatanan sosial dan budaya masyarakat (Jhingan, 2003:46). Pembangunan di negera maju dan negara berkembang sangatlah berbeda. Negara maju lebih mudah dalam mengendalikan setiap permasalahan pembangunan yang terjadi, karena tingkat sumber daya manusianya sudah cukup kompeten, ketersedian modal memadai, dan faktor-faktor pendorong pembangunan memang tertata dengan baik sehingga mampu menghasilkan kesejahteraan bagi negaranya. Namun berbeda halnya dengan negara berkembang yang masih cenderung banyak mengalami permasalahan dalam perekonomian, baik dari segi modal yang belum memadai, sumber daya manusia kurang kompeten, jumlah penduduk meningkat setiap tahunnya, dan distribusi pendapatan di masingmasing wilayah tidak merata. Indonesia merupakan negara kepulauan agraris yang terdiri dari beberapa pulau dengan total Provinsi sebanyak 34 provinsi. Dari masing-masing Provinsi yang ada, mempunyai potensi dan keanekaragaman yang berbeda. Namun walaupun begitu ketidakmerataan pembangunan masih belum stabil. Seperti halnya pembangunan dan pusat-pusat industri lebih berkembang di Indonesia bagian barat lebih tepatnya di Pulau Jawa dan sekitarnya. Dari tahun 2011 hingga tahun 2015, PDRB Indonesia selalu mengalami peningkatan yang cukup baik. Namun dengan adanya peningkatan total PDRB ini, belum tentu menunjukkan tingkat keseimbangan Pembangunan dalam setiap Provinsi yang ada.

Dalam data world bank menjelaskan bahwa dalam waktu lima belas tahun terakhir bahwa Indonesia mengalami pertumbuhan ekonomi yang kuat, dan telah mengurangi tingkat kemiskinan dan memperlebar jumlah kelas menengah. Namun dengan pertumbuhan ekonomi yang kuat ini lebih cenderung dinikmati oleh 20 persen masyarakat kaya, dan sekitar 80 persen penduduk atau lebih dari 205 juta orang rawan merasa tertinggal. Survei persepsi masyarakat tahun 2014 mengenai ketimpangan menunjukkan bahwa sebagian besar masyarakat Indonesia menilai distribusi pendapatan sangat tidak merata, lebih dari 61 persen responden mengatakan bahwa mereka dapat menerima pertumbuhan ekonomi yang rendah asalkan tingkat ketimpangan berkurang. berdasarkan laporan (Organization for Economic Cooperation and Development, 2015) disingkat OECD menjelaskan bahwa Indonesia kemiskinan sebagian besar, namun tidak sematamata, ditemukan di wilayah pedesaan dan pertanian yang merupakan tempat tinggal dari sekitar separuh jumlah penduduknya.

Pada tahun 2012, 14,3 persen penduduk desa berada di bawah garis kemiskinan pedesaan bila dibandingkan dengan penduduk kota yang hanya sebesar 8,4 persen, Bank Dunia (2012) memperkirakan bahwa 40 persen rakyat Indonesia memiliki kerentanan yang tinggi terhadap kemiskinan. Angka kemiskinan dapat dilihat berdasarkan nilai indek gini. Angka indeks gini nilainya berkisar antara 0 sampai 
dengan 1. Jika bernilai 0 maka menunjukkan terjadi pemerataan pendapatan secara sempurna atau dengan kata lain tingkat ketimpangan membaik. Sedangkan jika bernilai 1 maka pemerataan pendapatan tidak sempurna atau tingkat ketimpangan memburuk. Berdasarkan data BPS dijelaskan bahwa dalam kurun waktu 2011 sampai dengan 2015 Provinsi yang mempunyai nilai indeks gini tertinggi adalah DKI Jakarta, Jawa Barat, Sulawesi Selatan, Sulawesi Tenggara, Gorontalo, Papua Barat, dan Papua. Dalam penelitian ini keseluruhan Provinsi di Indonesia dibagi menjadi tiga wilayah studi. Wilayah I terdiri dari Provinsi yang berada di Pulau Sumatera dan Kalimantan, Wilayah II terdiri dari Provinsi yang berada di Pulau Jawa dan Bali-Nusa Tenggara, dan Wilayah III terdiri dari Provinsi yang berada di Pulau Sulawesi dan Papua. Pembagian ini didasarkan pada peraturan pemerintah tahun 2011 yaitu MP3El (Masterplan Percepatan dan Perluasan Pembanguan Ekonomi Indonesia) yang terdiri dari enam wilayah koridor pembangunan.

Berdasarkan Undang-undang Nomor 22 Tahun 1999/Nomor 32 Tahun 2004 Tentang Otonomi Daerah dan Undang-undang Nomor 25 Tahun 1999/Nomor 33 Tahun 2004 tentang Perimbangan Keuangan Pusat dan Daerah, adalah menunjukkan sebuah kebijakan dimana pemerintah pusat memberikan wewenang terhadap daerahnya untuk mengatur segala aktivitas terutama dalam pelaksanaan pelayanan publik. Dengan adanya peraturan ini akan lebih mempermudah pemerintah pusat dalam mengatur perekonomian, karena setiap daerah telah diberi kewenangan masing-masing mengembangkan wilayahnya. Biasanya daerah yang relatif maju berdampak pada perekonomian daerah disekitarnya. Dalam studi (Laswinia dan Chamid, 2016) mengenai pola hubungan spasial penduduk miskin dengan faktor lingkungan dan sosial ekonomi bahwa keragaman pembangunan terjadi pada variabel kepadatan penduduk, sedangkan variabel kepadatan persentase penduduk miskin terjadi hubungan antar lokasi dimana Provinsi yang letak geografisnya semakin ke timur memiliki persentase penduduk miskin yang semakin tinggi. Adanya perbedaan atau variasi antar pertumbuhan ekonomi yang dihasilkan masing-masing wilayah akan menimbulkan permasalahan baru yakni kesenjangan antar wilayah. Untuk itu diharapkan setiap daerah memiliki suatu hubungan atau keterkaitan dalam melaksanakan proses pembangunan. Berdasarka latar belakang diatas dapat diambil rumusan masalah sebagai berikut: (1) Bagaimana dampak disparitas spasial yang terjadi antar Provinsi di Indonesia?, (2) Bagaimana pengaruh variabel PAD, DAU, PDRB per kapita, PMA, dan PMDN terhadap tingkat disparitas wilayah yang terjadi?

Adapun tujuan dari penelitian ini adalah untuk menganalisis dampak disparitas spasial yang terjadi antar provinsi di indonesia, untuk menganalisis pengaruh variabel PAD, DAU, PDRB per kapita, PMA, dan PMDN terhadap tingkat disparitas wilayah yang terjadi. Manfaat dari penelitian ini adalah bagi peneliti sendiri adalah sebagai bahan pembelajaran dapat mengetahui bagaimana proses dan analisa mengenai pertumbuhan ekonomi yang mengikutsertakan unsur spasial antar wilayah studi. Untuk umum diharapkan dapat memberikan infomasi mengenai kasus yang sama dan juga sebagai sumber kajian bagi penelitian selanjutnya. Sedangkan untuk pemerintah atau instansi terkait diharapkan dapat menjadi dasar sebagai bahan penetapan kebijakan apa yang nantinya sesuai untuk pengembangan daerahnya.

\section{Metode Peneltian \\ Jenis Penelitian}

Jenis penelitian yang digunakan adalah penelitian deskriptif eksplanatori. Dimana secara deskriptis menjelaskan 
mengenai suatu masalah kejadian secara fakta ataupun realita. Sedangkan eksplanatori menerangkan suatu kejadian sebab akibat atau hubungan antar variabel. Dimana suatu kasus memiliki keunikan dan kemudian dicocokkan dengan teori-teori yang sesuai atau mengumpulkan jurnal sejenis.

\section{Waktu dan Tempat Penelitian}

Waktu penelitian disini berkisar mulai tahun 2011 sampai dengan tahun 2015 dengan merata-rata data menjadi satu dan menggunakan 34 provinsi sebagai cross section dan masing-masing dibagi menjadi 3 bagian berdasarkan enam wilayah koridor Provinsi yaitu wilayah I meliputi Koridor Sumatera dan Kalimantan (15 Provinsi), Wilayah II meliputi Koridor Jawa dan Bali-Nusa Tenggara (9 Provinsi), wilayah III meliputi Koridor Sulawesi dan Papua-Kep. Maluku (10 Provinsi). Alasan memilih Indonesia sebagai studi kasus, karena tingkat ketimpangan pendapatan di Indonesia masih tinggi. Dapat dilihat dari beberapa penelitian sebelumnya bahwa adanya perbedaan yang signifikan antara pembangunan Indonesia bagian barat dan bagian timur.

\section{Metode Analisis Data}

Metode analisis data yang digunakan adalah data panel dengan cara merata-rata data disetiap observasi yaitu dari tahun 2011 sampai dengan 2015. Untuk melihat seberapa besar keterkaitan antar daerah satu dengan daerah lainnya yang berdekatan dalam kurun waktu lima tahun tersebut dengan menggunakan software Geoda.
Sebelum memulai menganalisis spasial, maka perlu ditentukan matrik pembobot spasial terlebih dahulu. Matrik pembobot spasial (W) merupakan satuan yang diperoleh dari jarak antar region satu dengan region lainnya yang berdekatan. Menurut LeSage (1999) untuk menentukan matrik pembobot spasial dapat digunakan berapa metode yaitu: (1) Rook Contiguity (persinggungan sisi), dimana bobot antar wilayah $(\mathrm{wij})=1$ untuk wilayah yang bersisian (common side) dengan wilayah yang menjadi titik perhatian dan $w i j=0$ untuk wilayah lain yang tidak bersisian. (2) Linear Contiguity (persinggungan tepi) dimana wij = 1 untuk wilayah yang bersinggunan ditepi kiri dan kanan wilayah yang menjadi titik perhatian dan wij $=0$ wilayah lainnya yang tidak bersinggunan di tepi kiri dan kanannya. (3) Queen Contiguity (persinggungan sisi sudut) dimana Wij $=1$ wilayaha yang bersisian atau titik sudutnya bertemu dengan wilayah yang menjadi titik perhatian dan wij $=0$. (4) Bhisop Contiguity (persinggungan sudut) dimana wij $=1$ untuk wilayah yang titik sudutnya bertemu dengan wilayah pusat perhatian dan wij = 0 untuk wilayah lain yang titik sudutnya tidak bertemu. (5) Double Linear Contiguity (persinggungan dua tepi) dimana wij $=1$ untuk dua entity yang berada disisi (edge) kiri dan kanan wilayah perhatian dan wij = 0 untuk wilayah lainnya. (6) Double Rook Contiguity (persinggungan dua sisi) dimana wij = 1 untuk entity kiri, kanan, utara, dan selatan dari wilayah yang menjadi perhatian sedangkan wij $=0$ untuk wilayah lainnya.

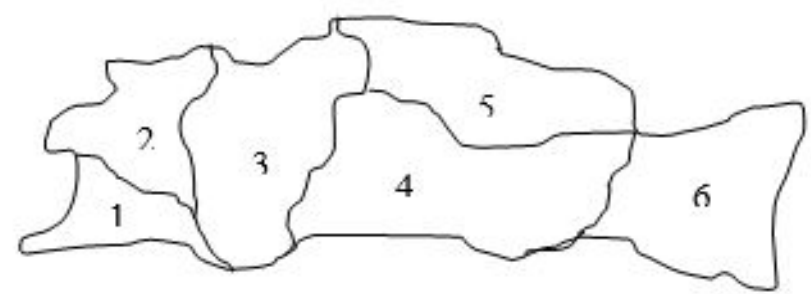

Gambar 1.

Ilustrasi Peta Menentukan Matrik Pembobot Spasial 
Dalam penelitian ini untuk menentukan matrik pembobot spasial akan menggunakan metode Rook Contiguity (persinggungan sisi). Berikut merupakan peta ilustrasi metode rook contiguity:

\section{Indeks Moran}

Untuk mengetahui ada tidaknya keterkaitan spasial pada variabel $\mathrm{Y}$, yang sebelumnya perlu diketahui nilai matrik pembobot spasial (W) dimana wilayah yang memiliki tetangga banyak maka nilai $\mathrm{W}$ akan semakin kecil, sebaliknya wilayah yang memiliki tetangga sedikit maka nilai W semakin besar.

$$
I=\frac{n \sum_{i=1}^{n} \sum_{j=1}^{n} w i j(x i-\dot{x})(x j-\dot{x})}{\sum_{i=1}^{n} \sum_{j=1}^{n} w i j \sum_{i=1}^{n} \sum_{j=1}^{n}(x i-\dot{x})^{2}}
$$

$\dot{\mathrm{x}}$ merupakan rata-rata observasi, wij adalah bobot keterkaitan antara wilayah $i$ dan $j$. untuk pengambilan keputusan keputusan ada tidaknya autokorelasi spasial antar lokasi yang menggunakan Indeks Moran adalah -1 dan 1.jika I > lo maka data mamiliki autokorelasi positif. Jika I < $I_{o}$ maka data memiliki autuporelasi negatif.

$$
E(I)=I_{0}=-\frac{1}{n-1}
$$

Dimana $E(I)$ merupakan expected value Moran's I

\section{Model Penelitian}

Dalam model penelitian ini mengadopsi dari model yang pernah dilakukan oleh (Hasnah, 2013) mengenai analisis spasial pengaruh dana perimbangan terhadap ketimpangan pendapatan di Provinsi Jawa Timur tahun 2008-2011, dengan model sebagai berikut:

Spasial Lag (SAR)

rgini $_{i}=\rho W$ rginijz $+\beta 1$ dana perimbangan ${ }_{i} t+$ $\beta 2$ TKindustri ${ }_{i} t+\beta 3$ TKterdidik ${ }_{i}+\beta 4$ Medis $_{i} t$ $+\beta 5 U M R_{i} t+\mu_{i t}+\varepsilon_{i t}$
Spasial Error (SEM)

rgini $_{i}=\beta 1$ dana perimbangan $i t+\beta 2$ TKindustri $_{i}+\beta 3$ TKterdidik $_{i t}+\beta 4$ Medis $_{i} t+$ $\beta 5 U M R_{i} t+\varnothing_{i t}$

$$
\emptyset i t=\rho \sum_{j=1}^{N} W i j \emptyset i t+\varepsilon i t
$$

Model modifikasi:

Spasial Lag (SAR)

rgini $_{i}=\partial W$ rginijt $+\beta 1 P A D_{i t}+\beta 2 P D R B$ PERKAPITA $_{i t}+\beta 3 D A U_{i t}+\beta 4$ PMDN $_{i t}+\beta 5$

$P M A_{i} t+\mu_{i} t+\varepsilon_{i} t$

Wilayah I

rgini $_{i t}=\partial W$ rginijt $+\beta 1 \quad P A D_{i t}+\beta 2 \quad P D R B$ PERKAPITA $_{i t}+\beta 3 D A U_{i t}+\beta 4$ PMDN $_{i t}+\beta 5$

$P M A_{i} t+\mu_{i} t+\varepsilon_{i} t$

Wilayah II

rgini $i_{i}=\partial W$ rginijz $+\beta 1 P A D_{i t}+\beta 2 P D R B$ PERKAPITA $_{i t}+\beta 3 D A U_{i t}+\beta 4$ PMDN $_{i t}+\beta 5$

$P M A_{i} t+\mu_{i} t+\varepsilon_{i} t$

Wilayah III

rgini $i_{i}=\partial W$ rginijz $+\beta 1 P A D_{i t}+\beta 2 P D R B$ PERKAPITA $_{i t}+\beta 3 D A U_{i t}+\beta 4 P_{P M D N}+\beta 5$

$P M A_{i} t+\mu_{i} t+\varepsilon_{i} t$

Spasial Error (SEM)

rgini $_{i}=\beta 1$ PAD $_{i t}+\beta 2$ PDRB PERKAPITA ${ }_{i} t+$ $\beta 3 D A U_{i t}+\beta 4 P M D N_{i t}+\beta 5 P M A_{i t}+\varnothing_{i t}$

$$
\emptyset i t=\rho \sum_{j=1}^{N} W i j \emptyset i t+\varepsilon i t
$$

Wilayah I

rgini $_{i}=\beta 1$ PAD $_{i t}+\beta 2$ PDRB PERKAPITA $A_{i}+$ $\beta 3 D A U_{i t}+\beta 4 P M D N_{i t}+\beta 5 P M A_{i t}+\emptyset_{i t}$

$$
\emptyset i t=\rho \sum_{j=1}^{N} W i j \emptyset i t+\varepsilon i t
$$


Wilayah II

rgini $_{i}=\beta 1$ PAD $_{i t}+\beta 2$ PDRB PERKAPITA ${ }_{i}+$ $\beta 3 D A U_{i t}+\beta 4 P M D N_{i t}+\beta 5 P M A_{i} t+\varnothing_{i t}$

$$
\emptyset i t=\rho \sum_{j=1}^{N} W i j \emptyset i t+\varepsilon i t
$$

Wilayah III

rgini $_{i}=\beta 1$ PAD $_{i t}+\beta 2$ PDRB PERKAPITA ${ }_{i} t+$ $\beta 3 D A U_{i t}+\beta 4 P M D N_{i t}+\beta 5 P M A_{i t}+\varnothing_{i t}$

$$
\emptyset i t=\rho \sum_{j=1}^{N} W i j \emptyset i t+\varepsilon i t
$$

\section{Uji Lagrange Multiplier}

Uji Lagrange Multiplier ini dimana untuk menentukan model terbaik antara model SAR atau SEM. (Laswinia dan Chamid, 2016) uji lagrange multiplier dengan hipotesis $\mathrm{HO}$ tidak ada dependensi spasial $\rho=0$ dan $\mathrm{H} 1$ ada dependensi spasial $\rho \neq 0$, dimana $W Y \rho=0$ maka model SEM lebih baik digunakan dibandingkan SEM, sedangkan jika nilai koefisien WY $\rho \neq 0$ maka model SAR lah yang lebih baik digunakan.

$$
L M \operatorname{lag}=\frac{\left(\frac{e^{\prime} W y}{\sigma^{2}}\right)^{2}}{\frac{(w x \beta)^{\prime} M W X \beta}{\sigma^{2}}+\operatorname{trace}\left[\left(W^{\prime}+W\right) W\right]}
$$

Untuk LM model spasial error digunakan untuk mengetahui apakah nilai koefisien $W \varepsilon \rho=0$ maka model SAR lebih baik digunakan dibandingkan SEM. Namun jika nilai koefisien $W \varepsilon \rho \neq 0$ maka model SEM lah yang lebih baik digunakan.

$$
L M \text { error }=\frac{\left(\frac{e^{\prime} W e}{\sigma^{2}}\right)^{2}}{\text { trace }\left[\left(W^{\prime}+W\right) W\right]}
$$

Apabila model yang terpilih keduanya maka diperlukan uji lanjutan yang dinamakan Uji Lagrange Multiplier Robbust, yaitu sama seperti uji LM seperti diatas yaitu untuk melihat apakah nilai koefisien WY dan WE sama dengan nol atau tidak, hanya saja berbeda pada statistik ujinya.

\section{Hasil dan Pembahasan Hasil Penelitian}

Berdasarkan perhitungan Indeks Moran untuk Variabel $Y$ pada Wilayah 1 sebesar 0,0018 lebih besar dari nilai $E(I)$ sebesar $-0,0714$ yang artinya terdapat hubungan autokorelasi spasial antar wilayah tetangga. Sedangkan untuk Wilayah II, nilai Indeks Moran pada wilayah ini sebesar 0,0718 dan untuk nilai $\mathrm{E}(I)$ sebesar $-0,1250$. Ini berarti nilai $/>\mathrm{E}(I)$ yang artinya terjadi hubungan autokorelasi spasial dalam wilayah. Untuk hasil perhitungan Indeks Moran pada Wilayah III yaitu sebesar 0,1669 sedangkan nilai $\mathrm{E}(I)$ sebesar $-0,1111$ dimana nilai $I>\mathrm{E}(I)$ yang berarti terjadi autokorelasi spasial di wilayah tersebut.

Berdasarkan nilai yang didapat pada tabel 1 , nilai LM $(\mathrm{lag})<\mathrm{a}=0,05$, dan $a=0,1$ sedangkan LM (error) $>a=0,05$ dan $a=0,1$. Maka model terbaik yang digunakan adalah model spatial lag.

Berdasarkan nilai tabel 2 pada kolom probabilitas dapat diketahui bahwa nilai LM lag sebesar 0,00785 $<a=0,05$ dan $a=0,1$ yang berati signifikan. Sedangkan untuk nilai LM error sebesar 0, $58877>a=$ 0,05 dan $a=0,1$ yang berati tidak signifikan Maka dapat disimpulkan untuk wilayah II, model terbaik adalah model spatial lag.

Berdasarkan uji LM pada tabel 3 dapat dilihat melaui nilai probabilitas di masing-masing model. Dimana nilai probabilitas dari LM lag sebesar 0,05388 $<a=0,05$ yang berarti model ini signigikan pada taraf alfa $a=0,05$. Sedangkan untuk model LM error nilai probabilitasnya sebesar 0,66928 $>a=0,05$ berarti model ini tidak signifikan pada taraf $a=0,05$ dan $a=0,1$. Jadi dapat disimpulkann bahwa model terbaik untuk wilayah III adalah model spasial lag. Dari hasil uji LM diatas baik Wilayah I, Wilayah II, dan Wilayah III, model spasial lag yang merupakan model terbaik yang dapat digunakan untuk estimasi selanjutnya. 
Hasil Pemilihan Model Spasial Lag dan Spasial Error

Tabel 1

Hasil Uji LM Wilayah I

\begin{tabular}{llcc}
\hline No & \multicolumn{1}{c}{ Uji } & Value & Prob \\
\hline 1. & $\begin{array}{l}\text { Lagrange } \\
\text { Multiplier (lag) }\end{array}$ & 8,5012 & 0,00355 \\
2. & $\begin{array}{l}\text { Robust LM } \\
\text { (lag) }\end{array}$ & 9,7275 & 0,00182 \\
3. & $\begin{array}{l}\text { Lagrange } \\
\text { Multiplier } \\
\text { (error) } \\
\text { Robust LM }\end{array}$ & 0,3779 & 0,53874 \\
& $\begin{array}{l}\text { Robur } \\
\text { (error) }\end{array}$ & 0,20531 \\
\hline
\end{tabular}

Sumber: Hasil Geoda (Diolah)

Tabel 2.

Hasil Uji LM Wilayah II

\begin{tabular}{clcc}
\hline No & \multicolumn{1}{c}{ Uji } & Value & Prob \\
\hline 1. & $\begin{array}{l}\text { Lagrange } \\
\text { Multiplier } \\
\text { (lag) }\end{array}$ & 7,0681 & 0,00785 \\
2. & $\begin{array}{l}\text { Robust LM } \\
\text { (lag) }\end{array}$ & 7,5966 & 0,00585 \\
3. & $\begin{array}{l}\text { Lagrange } \\
\text { Multiplier } \\
\text { (error) }\end{array}$ & 0,2923 & 0,58877 \\
4. & $\begin{array}{l}\text { Robust LM } \\
\text { (error) }\end{array}$ & 0,8208 & 0,36496 \\
Sumber: Hasil Geoda (Diolah) & \\
\hline
\end{tabular}

Tabel 3.

Hasil Uji LM Wilayah III

\begin{tabular}{clcc}
\hline No & \multicolumn{1}{c}{ Uji } & Value & Prob \\
\hline 1. & $\begin{array}{l}\text { Lagrange } \\
\text { Multiplier (lag) }\end{array}$ & 3,7163 & 0,05388 \\
2. & $\begin{array}{l}\text { Robust LM } \\
\text { (lag) }\end{array}$ & 3,5342 & 0,06012 \\
3. & $\begin{array}{l}\text { Lagrange } \\
\text { Multiplier } \\
\text { (error) } \\
\text { Robust LM } \\
\text { (error) }\end{array}$ & 0,1824 & 0,66928 \\
& 0,0003 & 0,98699 \\
\hline
\end{tabular}

Sumber: Hasil Geoda (Diolah) 
Tabel 4.

Hasil Estimasi Model Spasial Lag Wilayah I

\begin{tabular}{ccc}
\hline Variable & Coefficient & Probability \\
\hline W_Log_Gini & $-0,1789607$ & 0,00000 \\
Constant & $-0,4625358$ & 0,00000 \\
PAD & $-8,622154 \mathrm{e}-015$ & 0,11389 \\
PDRB Per k & $-7,86217 \mathrm{e}-010$ & 0,04356 \\
DAU & $-5,465344 \mathrm{e}-014$ & 0,10057 \\
PMDN & $2,023717 \mathrm{e}-015$ & 0,58722 \\
PMA & $2,099789 \mathrm{e}-015$ & 0,11146 \\
R Squared & \multicolumn{2}{c}{0,695629} \\
\hline
\end{tabular}

Sumber: Hasil Geoda (Diolah)

Tabel 5.

Hasil Estimasi Model Spasial Lag Wilayah II

\begin{tabular}{ccc}
\hline Variable & Coefficient & Probability \\
\hline W_Log_Gini & $-0,1526073$ & 0,00000 \\
Constant & $-1,029329$ & 0,00000 \\
PAD & $-6,132336 \mathrm{e}-014$ & 0,00000 \\
PDRB Per K & $1,451412 \mathrm{e}-008$ & 0,00000 \\
DAU & $4,544656 \mathrm{e}-013$ & 0,00000 \\
PMDN & $-1,873431 \mathrm{e}-015$ & 0,00495 \\
PMA & $6,491285 \mathrm{e}-015$ & 0,00000 \\
R Squared & \multicolumn{2}{c}{0,919500} \\
\hline
\end{tabular}

Sumber: Hasil Geoda (Diolah)

Tabel 6.

Hasil Estimasi Model Spasial Lag Wilayah III

\begin{tabular}{ccc}
\hline Variable & Coefficient & Probability \\
\hline W_Log_Gini & $-0,1513095$ & 0,00639 \\
Constant & $-0,4984567$ & 0,00000 \\
PAD & $7,756502 \mathrm{e}-014$ & 0,02934 \\
PDRB Per K & $8,080397 \mathrm{e}-010$ & 0,26232 \\
DAU & $1,472993 \mathrm{e}-014$ & 0,30624 \\
PMDN & $-4,061463 \mathrm{e}-014$ & 0,04808 \\
PMA & $-2,825016 \mathrm{e}-015$ & 0,32050 \\
R Squared & \multicolumn{2}{c}{0,710691} \\
\hline Sumber: Hasil Geoda (Diolah)
\end{tabular}

\section{Pembahasan}

Wilayah I ini merupakan pembagian antara Koridor Sumatera dan Koridor Kalimantan. Berdasarkan hasil pengujian secara spasial menunjukkan bahwa variabel aspek spasial pada indeks gini menun- jukkan pengaruh yang signifikan yaitu dengan nilai probabilitas sebesar 0,00000 yang berarti lebih kecil dari tingkat $a=0,05$ serta $a=0,1$ serta nilai koefisien sebesar $-0,1789607$. Sedangkan Wilayah II merupakan pembagian antara Koridor Jawa 
dan Bali-Nusa Tenggara. Berdasarkan hasil penelitian menunjukkan pengaruh yang signifikan dimana dengan nilai probabilitas sebesar 0,00000 yang berati nilainya lebih kecil dari tingkat alfa yang ditentukan yaitu $a=0,05$ serta $a=0,1$ dengan nilai koefisien sebesar -0,1526073. Dan untuk Wilayah III merupakan pembagian antara Koridor Sulawesi dan Koridor Papua-Kep Maluku. Berdasarkan hasil penelitian menunjukkan pengaruh yang signifikan dimana dengan nilai probabilitas sebesar 0,00639 berarti lebih kecil dari nilai $a=0,05$ dan $a=0,1$, serta nilai koefisien sebesar -0,1513095. Dapat diuraikan bahwa jika terjadi kenaikan indeks gini sebesar satu satuan, maka akan menurunkan nilai indeks gini diwilayah tetangga sebesar nilai koefisien dimasing-masing wilayah tersebut. Nilai indeks gini yang semakin berkurang menunjukkan tingkat ketimpangan yang semakin berkurang pula. Dan sebaliknya jika terjadi penurunan nilai indeks gini di wilayah akan menaikkan nilai indeks gini di wilayah tetangga. Dengan demikian dapat dilihat bahwa dengan arah koefisien negatif berarti dampak yang dihasilkan adalah tidak searah yang artinya tingkat kesenjangan pendapatan akan semakin terlihat.

Sesuai dengan teori Hirschman dengan konsep trickledown effect dimana yang menjelaskan bahwa proses pembangunan nantinya akan berdampak positif atau menyebar ke wilayah tetangga, namun sebaliknya jika lemah maka akan mengakibatkan polarisasi pertumbuhan dimana akan akan ada wilayah yang semakin maju dan ada wilayah yang semakin terbelakang, dan dalam jangka panjang akan mampu mengatasi masalah polarisasi yang terjadi diwilayah tetangga terbelakang. Dalam teori Perroux menjelaskan bahwa adanya inovasi baru yang dapat mempengaruhi kegiatan ekonomi di wilayah lainnya dengan memperlihatkan adanya kaitan erat antara skala, dominasi, dan dorongan-dorongan untuk melakukan penemuan yang memicu kegiatan ekono- mi yang baru. Sejalan dengan pendapat yang dikemuakkan oleh Myrdal bahwa model pembangunan adak ada dampak balik ataupun dampak sebar. Dimana dampak balik (Backwash Effect) merupakan suatu perubahan yang merugikan yang menyebar dari wilayah ke wilayah. Sedangkan dampak sebar (Spread Effect) merupakan dampak perubahan yang positif dan menyebar ke pusat-pusat potensial ke wilayah-wilayah.

\section{Pengaruh PAD Terhadap Ketimpangan Pendapatan}

Padal Wilayah I variabel PAD menunjukkan pengaruh yang tidak signifikan dengan nilai probabilias sebesar 0,11389 dimana lebih besar dari tingkat $a=0,05$ serta $a=0,1$ terhadap variabel $Y$ (indeks gini) dengan nilai koefisien sebesar -8,622154e-015. Hal ini berarti tingkat ketimpangan di Wilayah I tidak secara keseluruhan tidak dipengaruhi oleh variabel PAD melainkan ada faktor lain yang lebih berpengaruh terhadap tingkat ketimpangan pendapatan pada wilayah tersebut. Sedangkan untuk Wilayah II variabel PAD berpengaruh signifikan dengan nilai probabilitas sebesar 0,00000 lebih kecil dari $a=0,05$ serta $a=0,1$ dengan nilai koefisien regresi sebesar $-6,132336$ e014 hal ini mengindikasikan berarti setiap adanya kenaikan PAD sebesar satu satuan di Wilayah II maka akan menurunkan nilai indeks gini sebesar -6,132336e-014. Sejalan dengan penelitian Nurhuda et al. (2013) dimana PAD berpengaruh negatif dimana dengan naiknya variabel tersebut akan menurunkan tingkat ketimpangan yang ada. Kondisi ini merupakan suatu kondisi yang diinginkan setiap wilayah dimana indeks ketimpangan menurun seiring dengan adanya kegiatan ekonomi yang berlangsung secara berkelanjutan. Selain itu penelitian yang dilakukan oleh Putri dan Natha (2014) juga menunjukkan hasil yang sama yaitu PAD berpengaruh negatif signifikan terhadap ketimpangan 
pembangunan di Provinsi Bali, dimana dana PAD yang nantinya digunakan untuk alokasi pengeluaran pemerintah bukan belanja pembangunan yang nantinya dapat bermanfaat dimasa yang akan datang. Dan untuk Wilayah III variabel PAD juga berpengaruh secara signifikan terhadap indeks ketimpangan dengan nilai probabilitas sebesar 0,02934 yang berarti nilainya lebih kecil dari nilai $a=0,05$ serta $a=0,1$ dengan nilai koefisien sebesar 7,756502e014. Hal ini berarti bahwa setiap ada kenaikan PAD sebesar satu satuan di Wilayah III maka akan menaikkan nilai indeks gini sebesar 7,756502e-014. Hal ini sejalan dengan penelitian yang dilakukan oleh Wijayanto (2015) yang menjelaksan bahwa keterbukaan perdagangan, investasi asing langsung dan PAD berpengaruh positif terhadap ketimpangan pembangunan dalam jangka pendek maupun jangka panjang. Secara umum adanya kenaikan PAD diharapkan akan mampu menurunkan tingkat ketimpangan pendapatan yang ada di suatu wilayah khususnya pada Wilayah III ini. Wilayah III ini merupakan wilayah indonesia bagian timur dimana merupakan suatu wilayah yang cepat tumbuh namun kontribusi terhadap pertumbuhan ekonomi nasional masih sangat kecil.

\section{Pengaruh PDRB per Kapita Terhadap Ketimpangan Pendapatan}

Berdasarkan hasil penelitian pada Wilayah I, variabel PDRB per Kapita menunjukkan hasil yang signifikan dengan probabilitas sebesar 0,04356 yang berarti nilainya lebih kecil dari tingkat $a=0,05$ dan $a=0,1$ dengan nilai koefisien regresi sebesar -7,86217e-010. Hal ini dapat diartikan bahwa setiap ada kenaikan PDRB per kapita sebesar satu satuan maka akan menurunkan tingkat ketimpangan pendapatan sebesar $-7,86217$ e-010. Sejalan dengan konsep teori kesenjangan jangka panjang yang dikemukakan oleh Kuznet dimana dalam keadaan jangka panjang semakin tinggi nilai PDRB per kapita maka tingkat ketimpangan pembangunan akan semakin menurun. Sedangkan pada Wilayah II menghasilkan variabel PDRB per kapita berpengaruh secara signifikan dengan nilai probabilitas sebesar 0,00000 dan nilai koefisien regresi sebesar 1,451412e-008. Berdasarkan hasil tersebut maka setiap ada kenaikan PDRB per kapita sebesar satu satuan di Wilayah II maka akan menaikkan nilai indeks ketimpangan sebesar 1,451412e008. Sesuai dengan teori kesenjangan Kuznet jangka pendek, dimana pada tahap awal pembangunan meningkatnya PDRB per kapita justru akan semakin meningkatkan ketimpangan pembangunan. Hal ini sejalan dengan penelitian yang dilakukan Rosa dan Sovita (2016) yang menjelaskan bahwa PDRB per kapita, populasi penduduk, TPT, dan derajat disentralisasi fiskal berpengaruh secara positif dan signifikan di wilayah Pulau Jawa pada tahun 2009 - 2015. Seharusnya jika terjadi kenaikan PDRB per kapita dapat disimpulkan bahwa secara otomatis akan menurunkan tingkat kesenjangan pendapatan. Namun dalam studi Wilayah II ini justru meningkatkan nilai indeks ketimpangan. Hal ini dapat saja terjadi karena kenaikan PDRB per kapita di masing-masing daerah tidak sama. Jika suatu daerah tingakt PDRB per kapita naik belum tentu daerah lainnya juga akan naik. Adanya situasi seperti inilah yang nantinya akan memperburuk kondisi ketidakmerataan pembangunan. Berdasarkan surve persepsi masyarakat tahun 2014 mengenai ketimpangan menunjukkan bahwa sebagian besar masyarakat Indonesia menilai distribusi pendapatan sangat tidak merata, lebih dari 61 persen responden mengatakan bahwa mereka dapat menerima pertumbuhan ekonomi yang rendah asalkan tingkat ketimpangan berkurang.

Kuznet menjelaskan bahwa semakin tinggi PDRB atau PDRB perkapita maka akan semakin tingkat ketimpangan pendapatan yang terjadi karena akan se- 
makin menunjukkan perbedaan kaum miskin dan kaum kaya. Namun berbeda lagi dalam jangka panjang, seiring adanya proses pembangunan yang sustainable yang membuat masyarakat mampu berfikir lebih modern dan ingin memenuhi setiap kebutuhannya maka naiknya nilai PDRB per kapita justru akan mengurangi ketimpangan distribusi pendapatan. Dalam studi penelitian di Wilayah III diperoleh hasil variabel PDRB per kapita tidak secara keseluruhan tidak berpengaruh signifikan terhadap tingkat ketimpangan yang ada. Dengan nilai probabilitas sebesar 0,26232 yang berarti lebih besar dari nilai $a=0,05$ dan $a=0,1$ dan koefisien regresi sebesar $8,080397 e-010$. Dengan kata lain bahwa ada variabel penentu lain dalam mengukur indeks ketimpangan pendapatan di Wilayah III ini. Hasil ini bertolak belakang dari teori yang dikemukakan oleh Kuznet yang mengusung konsep perubahan pembangunan yang ditandai oleh nilai PDRB per Kapita daerah yang nantinya dalam jangka panjang akan mengurangi tingkat ketimpangan pembangunan.

\section{Pengaruh DAU Terhadap Ketimpangan Pendapatan}

Dalam hasil analisis pada penelitian ini, variabel DAU di Wilayah I berpengaruh signifikan dengan nilai probabilitas sebesar 0,10057 yang nilainya tepat pada $a=$ 0,01 dan nilai koefisien regresi sebesar $-5,465344 \mathrm{e}-041$. Hal ini dapat diartikan bahwa setiap ada kenaikan DAU sebesar satu satuan maka akan menurunkan nilai indeks ketimpangan sebesar $-5,465344$ e041. Hasil ini sejalan dengan penelitian yang dilakukan oleh Dhyatmika dan Atmanti (2013) dimana menjelaskan bahwa variabel pengeluaran pemerintah berpengaruh secara negatif dan signifikan terhadap ketimpangan pembangunan di Kabupaten/Kota Provinsi Banten pasca pemekaran wilayah. Penelitian yang sama juga dilakukan oleh Zasriati (2011) dimana DAU berpengaruh negatif signifikan terha- dap tingkat ketimpangan pembangunan di Provinsi Jambi. DAU disini termasuk dalam pengeluaran pemerintah yang bersumber dari dana APBN yang kemudian ditransfer ke daerah dengan jumlah yang berbeda di masing-masing wilayah catatan berdasarkan kebutuhan dan kapasitas fiskal yang ada di wilayah tersebut. daerah yang mempunyai kapasitas fiskal besar namun kebutuhan akan fiskalnya kecil maka akan memperoleh DAU yang relatif kecil, sebaliknya bagi daerah yang mempunyai kapasitas fiskal kecil, namun kebutuhan fiskalnya besar maka akan mendapatakn DAU relatif besar.

Untuk hasil penelitian di Wilayah II menunjukkan bahwa variabel DAU berpengaruh secara signifikan dengan nilai probabilitas sebesar 0,00000 dan nilai koefisien regresi sebesar 4,544656e-013. Dari hasil tersebut dapat dijelaskan bahwa setiap ada kenaikan DAU sebesar satu satuan maka akan menaikkan tingkat ketimpangan pendapatan pada Wilayah II. Hal ini dapat dilihat pada pembagian dana alokasi di masing-masing provinsi bagian Wilayah II. Dimana DAU untuk wilayah DKI Jakarta dan DI Yogyakarta dari tahun 2011 sampai denga tahun 2015 menunjukkan angka yang relatif kecil dibandingkan DAU Provinsi lainnya di Wilayah II. Padahal apabila dilihat dari nilai indeks gini baik pada DKI Jakarta dan DI Yogyakarta menunjukkan nilai yang relatif besar yaitu kisaran $>0,4$ dibanding Provinsi lainnya di Wilayah II. Memang walaupun nilainya kecil namun setiap tahunnya mengalami peningkatan jumlah DAU, hanya saja jumlahnya tidak sebanding dengan nilai DAU masing-masing provinsi yang mempunyai nilai indeks gini lebih kecil. Penelitian ini sejalan dengan penelitian yang dilakukan Putri dan Natha (2014) dimana yang menjelaskan bahwa variabel DAU menunjukkan nilai yang signifikan dengan arah koefisien positif dimana dengan meningkatnya akan menyebabkan kenaikan pada ketimpangan di Provinsi Bali. 
Untuk hasil penelitian di Wilayah III menunjukkan bahwa variabel DAU tidak secara keseluruhan tidak berpengaruh terhadap tingkat ketimpangan pendapatan di Wilayah III. Dimana nilai probabilitas sebesar 0,30624 dengan nilai koefisien regresi sebesar 1,472993e-014. Hal ini dikarenakan adanya faktor lain yang lebih dominan yang berkorelasi dalam model. Hasil ini sama dengan hasil penelitian yang dilakukan oleh Nurhuda et al (2013) dimana variabel DAU tidak berpengaruh signifikan terhadap tingakat ketimpangan pembangunan di Provinsi Jawa Timur. Dalam pandangan secara nasional dana perimbangan termasuk di dalamnya adalah DAU dimaksudkan pemerintah guna untuk menambah dalam pembiayaan keuangan daerah agar mampu menjalankan program pembangunan yang bersifat sustainable dalam jangka panjang. Dimana yang sesuai dengan peraturan disentralisasi fiskal yang memberikan wewenang daerah untuk mengembangkan wilayahnya sendiri secara mandiri yang nantinya mampu menghasilkan suatu wilayah yang sejahtera sesuai dengan tujuan nasional. Semakin kecil transfer pemerintah pusat kepada daerah atau ketergantungan terhadap pemerintah pusat, dapat dikatakan semakin berkembang pula suatu daerah tersebut.

\section{Pengaruh PMDN Terhadap Ketimpan- gan Pendapatan}

Dalam hasil analisis regresi pada Wilayah I bahwa variabel PMDN tidak secara keseluruhan tidak berpengaruh terhadap tingkat ketimpangan pembangunan di Wilayah I dengan nilai probablitas sebesar 0,58722 yang artinya lebih besar dari tingkat $a=0,05$ dan $a=0,1$ dengan nilai koefisien regresi sebesar 2,023717e015. Hal ini bisa saja terjadi dikarenakan bahwa tingkat PMDN di Wilayah I dari periode 2011 sampai dengan 2015 bergerak fluktuatif dan nilai disetiap Provinsi tidak sama. Kondisi demikian sejalan dengan penelitian yang dilakukan oleh Puntri (2016) menjelaskan bahwa investasi tidak berpengaruh secara signifikan terhadap kesenjangan pendapatan di Kabupaten/ Kota di Provinsi Jawa Barat, Jawa Tengah, dan Jawa Timur.

Berbeda lagi dengan Wilayah II dimana variabel PMDN berpengaruh signifikan terhadap tingkat ketimpangan dengan nilai probabilitas sebesar 0,00495 yang berarti lebih kecil dari nilai $a=0,05$ dan $a=0,1$. Sedangkan untuk nilai koefisien regresi untuk vaiabel ini bernilai negatif yaitu sebesar $-1,873431$. Dimana setiap ada kenaikan PMDN sebesar satu satuan di Wilayah II maka akan menurunkan tingkat kesenjangan pendapatan sebesar $-1,873431$. Hal ini menunjukkan situasi yang bagus dimana adanya penuruan ketimpangan seiring adanya kenaikan PMDN. Dan sesuai dengan teori pertumbuhan yang ditetapkan oleh Harod-Domar dimana adanya tingkat investasi yang nantinya akan memicu pertumbuhan ekonomi disuatu daerah. Melalui pertumbuhan ekonomi, secara bertahap akan mengurangi tingkat kesenjangan yang terjadi antar daerah itu sendiri. Hal ini sejalan denga penelitian yang dilakukan oleh $\mathrm{Hi}$ dayat (2014) menjelaskan bahwa variabel investasi berpengaruh negatif signifikan terhadap tingkat ketimpangan pendapatan antar daerah. Diwilayah III variabel PMDN berpengaruh signifikan terhadap indeks ketimpangan, dimana dengan nilai probabilitas sebesar 0,04808 yang artinya lebih kecil dari nilai $a=0,05$ dan $a=0,1$. Sedangkan untuk nilai koefisien regresi bertanda negatif yaitu sebesar $-4,061463 e-014$, yang artinya setiap ada kenaikan PMDN sebesar satu satuan di Wilayah III maka akan menurunkan tingkat ketimpangan pendapatan sebesar $-4,061463 e-014$. Kondisi demikian sama halnya dengan apa yang terjadi pada Wilayah II. Adanya kondisi demikian memang cukup bagus terutama dalam rangka pengurangan ketidakmerataan pendapa- 
tan daerah. Dengan demikian pemerintah perlu mengatur lebih dalam lagi mengenai alokasi dana PMDN yang tersebar disetiap wilayah.

Dalam konteks secara nasional, pada Wilayah I jelas bahwa PMDN tidak berpengaruh secara signifikan, sedangkan untuk Wilayah II dan III adanya PMDN justru mengurangi tingkat ketidakmerataan pendapatan. Mengapa terjadi perbedaan demikian? Dapat disebabkan oleh bermacam faktor diluar variabel pemodelan. Bisa saja seperti tingkat pengangguran yang ada belum mampu terserap oleh adanya PMDN disuatu daerah, tingkat pendidikan yang kurang memadai, karena jika setiap proyek investasi seseorang yang bekerja justru didominasi oleh orang yang berpendidikan lebih tinggi, maka peluang untuk seseorang yang berpendidikan rendah akan semakin kecil pula. Untuk itu disinilah peran pemerintah sangat dibutuhkan terutama bagi wilayah-wilayah yang kurang berkembang, diharapakan akan mampu menciptakan kesetataraan yang sesuai, tidak hanya pada kalangan atas tetapi juga kalangan bawah. Sekecil apapun perubahan yang dilakukan pemerintah dapat dikatakan berhasil, namun jika dampaknya dapat dinikmati oleh seluruh lapisan masyarakat, yang pada akhirnya akan mengurangi jurang pemisah antara kaum kaya dan kaum miskin.

\section{Pengaruh PMA Terhadap Ketimpangan Pendapatan}

Pada Wilayah I dihasilkan bahwa variabel PMA tidak secara keseluruhan tidak berpengaruh terhadap indeks ketimpangan dengan nilai probabilitas sebesar 0,11146 yang berarti lebih besar dari standart $a=0,05$ dan $a=0,1$ dengan nilai koefisien regresi senilai 2,099789e015. Dimana setiap ada kenaikan PMA sebesar satu satuan tidak akan menambah atau mengurangi tingkat ketimpangan pendapatan di Wilayah I. Pada Wilayah II dihasilkan bahwa variabel PMA berpenga- ruh signifikan terhadap indeks ketimpangan pendapatan dengan nilai probabilitas sebesar 0,00000 yang berarti lebih kecil dari nilai $a=0,05$ dan $a=0,1$, dan nilai koefisien regresi sebesar 6,491285e015. Dimana setiap ada kenaikan PMA sebesar satu satuan, akan meningkatkan pula nilai indeks ketimpangan di Wilayah II. Seharusnya nilai PMA yang semakin naik justru lebih menurunkan tingkat ketimpangan yang ada. Namun kondisi ini berbanding berbalik dengan hasil penelitian. Padahal secara umum nilai investasi yang paling berkembang ialah terjadi di Wilayah II. Hal ini sejalan dengan penelitian yang dilakukan oleh Dhyatmika dan Atmanti (2013) dimana menjelaskan bahwa PMA berpengaruh positif signifikan terhadap tingkat ketimpangan pembangunan di Provinsi Banten, dimana penyebaran PMA yang tidak merata antar daerah akan dapat menyebabkan tingkat ketimpangan semakin melebar. Misalnya saja ada suatu daerah yang tingkat investasinya bagus namun berbeda lagi dengan daerah yang tingkat investasinya kurang bagus. Disinilah dapat dilihat bahwa daerah yang semakin tinggi kegiatan investasinya maka daerah tersebut akan semakin kaya, sedangkan untuk daerah yang peluang investasinya sedikit, justru akan semakin kecil, banyaknya pengangguran yang kurang terserap, sumber daya alam tidak dapat terpakai secara optimal, dll. penelitian pendukung lainnya ialah penelitian yang yang dilakukan oleh Wijayanto (2015) yang menjelaksan bahwaa variabel investasi asing langsung berpengaruh positif terhadap ketimpangan pembangunan dalam jangka pendek maupun jangka panjang. Sedangkan untuk Wilayah III menghasilkan bahwa variabel PMA tidak secara keseluruhan tidak berpengaruh signifikan terhadap indeks ketimpangan pendapatan dengan nilai probabilitas sebesar 0,32050 yang artinya lebih besar dari nilai $a=0,05$ dan $a=0,1$, dan nilai koefisien regresi sebesar -2,825016-015. 
Dimana setiap ada kenaikan PMA sebesar satu satuan tidak akan menambah atau mengurangi tingkat ketimpangan pendapatan di Wilayah III. Dapat dilihat pada Wilayah I dan III adanya PMA tidak secara keseluruhan akan menambah atau mengurangi tingkat distribusi pendapatan yang ada, dimana variabel PMA tidak berpengaruh baik di Wilayah I ataupun Wilayah II. Penelitian ini didukung oleh fakta empiris yang dilakukan oleh Adipuryanti dan Sudibia (2015) menjelaskan bahwa variabel investasi tidak berpengaruh signifikan terhadap tingkat ketimpangan distribusi pendapatan di Provinsi Bali.

\section{Kesimpulan dan Rekomendasi Kesimpulan}

Hasil analisis regresi menunjukkan model terbaik adalah Spatial Lag bahwa variabel aspek spasial baik di Wilayah I Wilayah II, dan Wilayah III menunjukkan adanya interaksi spasial antar wilayah secara signifikan dengan arah negatif, dimana setiap adanya perubahan indeks gini di wilayah studi maka akan mempengaruhi nilai indeks gini di wilayah tetangga. Variabel PAD pada Wilayah I menunjukkan pengaruh yang tidak signifikan. Artinya ketimpangan di Wilayah I tidak secara keseluruhan tidak dipengaruhi oleh variabel PAD melainkan ada faktor lain yang lebih berpengaruh terhadap tingkat ketimpangan pendapatan pada wilayah tersebut Sedangkan pada Wilayah II PAD berpengaruh positif signifikan. Hal ini mengindikasikan berarti setiap adanya kenaikan PAD sebesar satu satuan maka akan menurunkan nilai indeks gini di Wilayah II. Untuk Wilayah III PAD juga berpengaruh secara positif signifikan terhadap indeks ketimpangan. Hal ini berarti bahwa setiap ada kenaikan PAD sebesar satu satuan maka akan menaikkan nilai indeks gini di Wilayah III. Variabel PDRB per Kapita pada Wilayah I menunjukkan hasil yang negatif signifikan Dapat diartikan bahwa setiap ada kenaikan PDRB per kapita sebesar satu satuan maka akan menu- runkan tingkat ketimpangan pendapatan di Wilayah I. Pada Wilayah II menghasilkan variabel PDRB per kapita berpengaruh secara positif signifikan, dimana setiap ada kenaikan PDRB per kapita sebesar satu satuan maka akan menaikkan nilai indeks ketimpangan di Wilayah II. Untuk Wilayah III variabel PDRB per kapita tidak secara keseluruhan tidak berpengaruh signifikan terhadap tingkat ketimpangan yang ada. Variabel DAU pada Wilayah I berpengaruh negatif signifikan, dapat diartikan bahwa setiap ada kenaikan DAU sebesar satu satuan maka akan menurunkan nilai indeks ketimpangan di Wilayah II. Untuk Wilayah II variabel DAU berpengaruh secara positif signifikan, dimana setiap ada kenaikan DAU sebesar satu satuan maka akan menaikkan tingkat ketimpangan pendapatan pada Wilayah II. Sedangkan untuk Wilayah III DAU tidak secara keseluruhan tidak berpengaruh terhadap tingkat ketimpangan pendapatan di Wilayah III. Hal ini dikarenakan adanya faktor lain yang lebih dominan yang berkorelasi dalam model. Variabel PMDN pada Wilayah I bahwa variabel PMDN tidak secara keseluruhan tidak berpengaruh terhadap tingkat ketimpangan pembangunan di Wilayah I. Pada Wilayah II PMDN berpengaruh negatif signifikan terhadap tingkat ketimpangan. Dimana setiap ada kenaikan PMDN sebesar satu satuan maka akan menurunkan tingkat kesenjangan pendapatan di Wilayah II. Dan untuk Wilayah III PMDN berpengaruh negatif signifikan terhadap indeks ketimpangan, yang artinya setiap ada kenaikan PMDN sebesar satu satuan maka akan menurunkan tingkat ketimpangan pendapatan di Wilayah III. Variabel PMA pada Wilayah I menunjukkan tidak secara kesluruhan tidak berpengaruh terhadap indeks ketimpangan. Dimana setiap ada kenaikan PMA sebesar satu satuan tidak akan menambah atau mengurangi tingkat ketimpangan pendapatan di Wilayah I. Sedangkan untuk Wilayah PMA berpengaruh positif signifikan terhadap indeks ketimpa- 
ngan pendapatan. Dimana setiap ada kenaikan PMA sebesar satu satuan, akan meningkatkan pula nilai indeks ketimpangan di Wilayah II. Untuk Wilayah III PMA tidak secara keseluruhan tidak berpengaruh signifikan terhadap indeks ketimpangan pendapatan. Dimana setiap ada kenaikan PMA sebesar satu satuan tidak akan menambah atau mengurangi tingkat ketimpangan pendapatan di Wilayah III.

\section{Rekomendasi}

Berdasarkan kesimpulan diatas dapat diambil rekomendasi kebijakan yang nantinya ditetapkan untuk pemerintah dalam mengurangi ketidakmerataan pendapatan yang terjadi diantaranya:

Pertama, dalam rangka pengurangan ketimpangan pendapatan, ada baiknya pemerintah lebih memperhatikan lagi kondisi daerah yang masih tertinggal, tidak hanya terfokus pada daerah yang sudah maju. Untuk kebijakan dana pembangunan antar pusat ke daerah, perlu diperhatikan kapasitas fiskal setiap daerah agar dana yang dikeluarkan sesuai dengan apa yang dibutuhkan oleh daerah tersebut. Sedangkan untuk penanaman modal baik penanaman modal asing ataupun investasi swasta, ada baiknya lebih digerakkan terutama bagi daerah-daerah yang masih minim investasi seperti wilayah bagian timur Indonesia. Saat ini pemerintah telah mempermudah akses berinvestasi. Hal ini akan memicu timbulnya banyak industri baru di daerah sehingga akan berdampak pada pertumbuhan ekonomi dimana meliputi banyak terciptanya lapangan kerja sehingga akan berdampak pada perbaikan tingkat pendapatan masyarakat, pengurangan jumlah pengangguran, dll. Namun jika dampak baik investasi ini hanya dinikmati oleh kalangan tertentu saja, maka yang terjadi ialah kesenjangan akan semakin meningkat.

Kedua, dengan diberlakukannya kebijakan MP3EI pada 20 Mei 2011, diharapkan akan mampu merealisasi- kan tujuannya dimana untuk mewujudkan pertumbuhan yang seimbang dan berkelanjutan di seluruh pelosok negeri berdasarkan pembagian koridor wilayah ekonomi sesuai dengan potensi yang dimiliki, terutama pada Wilayah Indonesia bagian timur. Program ini cukup bagus diterapkan dalam prospek pembangunan di Indonesia. Untuk itu pemerintah harus benar-benar menjalankan kebijakan ini sesuai dengan tujuan yang ditetapkan dengan cara mensosialisasikan program ini ke seluruh kalangan masyarakat tanpa terkecuali agar masyarakat mengerti bagaimana kebijakan yang nantinya diterapkan pemerintah untuk membangun negeri. Karena suatu program tidak akan berhasil apabila elemen-elemen didalamnya tidak turut mendukung.

\section{Daftar Pustaka}

Adipuryanti., Ni Luh Putu. Yuni, I K. Sudibia. 2015. Analisis Pengaruh Jumlah Penduduk Yang Bekerja Dan Investasi Terhadap Ketimpangan Distribusi Pendapatan Melalui Pertumbuhan Ekonomi Kabupaten/Kota Di Provinsi Bali. Piramida jurnal kependudukan dan pengembangan sumber daya manusia volume XI NO. 1:20-28 2015 ISSN : 1907-3275.

Boediono. 1981. Teori Pertumbuhan Ekonomi Seri Sonopsis Pengantar IImu Ekonomi No.4.Yogyakarta: BPFE.

Dhyatmika, K.W, dan. H. D. Atmanti. 2013. Analisis Ketimpangan Pembangunan Provinsi Banten Pasca Pemekaran. Volume 2, Nomor 2, Tahun 2013, Halaman 1- 8 ISSN (Online): 2337-3814.

Hasna, S. 2013. Analisis Spasial Pengaruh Dana Perimbangan Terhadap Ketimpangan Pendapatan di Provinsi Jawa Timur. Jurnal BPPK, Volume 6 Nomor 2, 2013, Halaman 1-18.

Hidayat, M. H. 2014. Analisis Pengaruh Pertumbuhan Ekonomi, Investasi, Dan Ipm 
Terhadap Ketimpangan Pendapatan Antar Daerah Di Provinsi Jawa Tengah Tahun 2005-2012. Skripsi Universitas Diponegoro.

Jhingan, M.L. 2003. Ekonomi Pembangunan dan Perencanaan. Jakarta: PT Raja Grafindo Persada.

Laswinia, V. D, dan M. S. Chamid. 2016. Analisis Pola Hubungan Persentase Penduduk Miskin dengan Faktor Lingkungan, Ekonomi, dan Sosial di Indonesia Menggunakan Regresi Spasial. Jurnal Sains Dan Seni Its Vol. 5 No. 2 (2016) 2337-3520 (2301-928x Print).

Nurhuda, R., M.R.K. Muluk, Y. P. Prasetyo. 2013. Analisis Ketimpangan Pembangunan (Studi Kasus Di Provinsi Jawa Timur Tahun 2005-2011. Jurnal Administrasi Publik (JAP), Vol. 1, Nomor 4, Hal. 110-119.

Puntri, Q. G. 2016 Pengaruh Pengeluaran Pemerintah Dan Investasi Terhadap Pertumbuhan Ekonomi Dan Kesenjangan Pendapatan (Studi Empiris Pada Kabupaten/Kota Provinsi Jawa Barat, Jawa Tengah, Dan Jawa Timur Tahun 2011-2013). Skripsi Universitas Muhammadiyah Surakarta.

Putri, Ni, Putu, Shanty, Valentiana dan Natha, I, Ketut, Suardika. 2014. Pengaruh Pendapatan Asli Daerah, Dana Lokasi Umum, Belanja Modal Terhadap Ketimpangan Distribusi Pendapatan. E-jurnal EP Unud, 4 (1) : 41-49 ISSN: 2303-9178.

Rossa, Y. D, dan I. Sovita. 2016. Analisis Faktor-Faktir Yang Mempengaruhi Ketimpangan Distribusi Pendapatan Di Pulau Jawa. Menara Ekonomi: ISSN: 2470 - 8585 Volume II No. 4 - Oktober 2016.

Wijayanto, D. 2015. Pengaruh Liberalisasi Perdagangan Dan Disentralisasi Fiskal
Terhadap Pertumbuhan Dan Ketimpangan Wilayah Di Indonesa. Skripsi Institut Pertanian Bogor.

Zasriati, M. 2011. Pengaruh Alokasi Dan Perimbangan Terhadap Ketimpangan Ekonomi Regional Di Provinsi Jambi. Tesis Universitas Andalas Padang.

https://www.oecd.org/economy/OverviewIndonesia-2015-Bahasa.pdf

http://www.worldbank.org/in/news/feature/2015/12/08/indonesia-rising-divide

www.bps.go.id 